\title{
THE CONFLICT BETWEEN PARTISAN INTERESTS AND NORMATIVE EXPECTATIONS IN ELECTORAL SYSTEM CHANGE. HUNGARY IN 2014
}

\author{
RÉKA VÁRNAGY AND GABRIELLA ILONSZKI
}

\begin{abstract}
Academic literature is divided about the importance of the normative versus the partisan background of electoral system change. While concerns regarding the former electoral system were justified in Hungary the article argues that the actual reform dominantly followed partisan interests and even neglected normative concerns. Applying the approach of the Electoral Integrity Project the analysis of various aspects, like the electoral law itself, electoral procedures, voter registration, party and candidate registration, media coverage, campaign finance, voting process, vote count, and the role of electoral authorities demonstrates that Hungary's ranking is strikingly low for almost every element, often ranking last from a comparative perspective. The new electoral system is a building block in the construction of a predominant party system.
\end{abstract}

KEYWORDS: electoral system change, electoral integrity, majoritarian turn, partisan redistribute interests

\section{INTRODUCTION}

The expanding literature on electoral reform has proposed a comprehensive approach towards electoral system change, arguing that looking beyond the simple logic of maximizing gains for the dominant political elite allows for the assessment of the normative drivers behind such change (Hazan - Leyenaar

\footnotetext{
1 Réka Várnagy is associate professor and Gabriella Ilonszki is professor emerita of the Corvinus University of Budapest, e-mails: reka.varnagy@uni-corvinus.hu, gabriella.ilonszki@uni-corvinus. hu. The authors would like to acknowledge the support of the OTKA National Research Foundation which made the research for this paper possible (OTKA K 10622).
} 
2014). Indeed, electoral systems tend to fulfil normative expectations like providing fair representation and stable government. More nuanced, practical concerns such as making elections cheaper or more intelligible are also regarded as positive outcomes. However, these normative goals are intermingled with the rule-makers' political interests. The delicate balance between normative goals and strategic partisan goals becomes highly visible at the moment of electoral system change. Academic literature is divided about the importance of the normative versus the partisan background of electoral system change. Rational choice literature argues for the supremacy of partisan interests in the formation (transformation) of electoral system design (Benoit 2004, Colomer 2005), claiming that seat maximization is the parties' main interest. Others (Shugart 2001) focus on normative claims: if the electoral system does not bring representative demands to the surface, or the prospective formation of a government remains opaque to voters in the electoral process, or the mandate majority counters the voters' electoral majority, the electoral system is unbalanced and requires modification on normative grounds.

However, as Bowler and Donovan note: "When elites want to change institutions, however, appeals to narrow self-interested or partisan goals seem somehow inappropriate or at least ineffective. Appeals grounded in an overexpression of self-interest are not used very frequently despite the fact that selfinterest is a major component of how institutions, and institutional changes, are understood. Instead, campaigners focus on the procedural and conceptual consequences of institutional change." (2013:45).The authors suggest making a clear distinction between the arguments for change (along with the promises that are made) and the actual results of the reform process. With an analysis of the new electoral system that was introduced in Hungary in 2011 and was first implemented at the 2014 parliamentary elections, we explore the connection between normative and partisan motives and the actual outcomes of the new electoral design. We argue that while there existed a broad array of arguments for change mainly based on normative claims, the actual reform dominantly followed partisan interests and even neglected normative concerns. Analysis of the Hungarian case can enrich our understanding of the limitations of the normative approach to electoral reform and explain how the pressure to answer to the electorate interacts with strategically driven reform processes.

The electoral reform in Hungary was vigorously debated, even provoking international interest and criticism, notably by the Venice Commission (an organization of the Council of Europe that oversees the state of democracy in different countries) and the OECD/ODIHIR and was part of a broad institutional process of transformation. This increases the relevance of our research question which may be framed as: 'how were normative demands and expectations 
implemented by the governing majority?' Our analysis is structured along three claims: the first is that normative concerns served as a starting point for the Hungarian reform because concerns regarding the former electoral system were justified and corrections were due. Our second claim is that partisan interests overruled normative and practical considerations in the formation of the new electoral rules. In order to comprehend the partisan aspect of electoral reform, we are required to ask "why, when and in what form" questions, as Katz eloquently formulated it (Katz 2005). Finally, by placing the new electoral system into the frame of electoral integrity we demonstrate in what respect the new electoral design is responding to normative and partisan interests.

\section{NORMATIVE CLAIMS}

The old electoral system (Law XXXIV of 1989) was designed in the process of negotiations between post-communist and new opposition parties during the change of system and was a true compromise in the sense that it reflected the priorities of the different actors: the post-communists' desire to create singlemember districts (SMDs) (as their cadres had local ties) and the new parties' demands for proportionality (as the new party labels were assumed to be more telling than their still largely unknown personalities). The mixed-member system responded to both expectations. In addition to the SMDs, other instruments, which generally represented entry barriers to smaller parties, also supported the electoral system's majoritarian bias. The two territorial tiers (the regional and the national) did not reduce disproportionality. Due to the small magnitude of districts, the territorial lists favored bigger parties, and only in Budapest (where the district size was bigger) were smaller parties able to win mandates (Fábián 1999). The two biggest parties always won more than 60 percent of territorial mandates, a proportion that rose above 90 percent with the concentration of the party system in the $2000 \mathrm{~s}$. The entry of smaller parties was also constrained because only those parties could set up a regional list that were able to run candidates in at least one-third of the region's SMDs, and only those parties could set up a national list that had established at least seven regional lists. Still, the national list guaranteed proportionality to some degree as the fragmented votes from SMDs and regional lists were added up and earned mandates, there being no votes cast on the national list.

On these grounds concerns with respect to representation became explicit as smaller parties were placed in a disadvantageous position: not only the threshold requirement but the regional list requirements, not to mention the 
advantage of big parties in SMDs, reduced their electoral opportunities. A particular problem with representation concerned ethnic minorities which were given a constitutional warrant for fair representation by the modified Hungarian Constitution in 1990. According to the ruling of the Hungarian Constitutional Court, the absence of minority representation in the parliament was unconstitutional (35/1992.Resolution (VI.10) and needed remedy.

In contrast, the electoral system well served the idea of governability as at each election it ensured a majority coalition government. Of course, coalition formation is also a function of parties' coalition potential, but relative majority winners were always able to establish stable coalitions with junior partner(s). In 1994, one party even managed to gain an absolute majority of seats and formed an oversize coalition with a more-than-two-thirds majority. This type of supermajority reoccurred as a result of the 2010 elections. The significance of this event is that certain laws, including the electoral law, can be amended only with a twothirds majority. We shall return to the significance of this condition in the next section during an analysis of the moments of change. Overall, as a result of the stable party system, along with the electoral rules, governability prevailed, which distinguished Hungary from most new democracies in Central Eastern Europe.

Some further problems with the functioning of the electoral system were highly visible. Most importantly, party finance and campaign finance regulations were a cause of concern. These were not transparent and gave an advantage to the larger parties represented in parliament. The regulations were articulated in the transition period of the early 1990s and represented the priorities of the negotiating parties, most of whom became parliamentary parties, making them resistant to change. State subsidies were provided to parties that received at least 1 percent of the vote at the preceding election, with 25 percent of the subsidy divided equally among parliamentary parties that had won mandates on the national list and 75 percent divided in proportion to vote share among all parties that reached the 1 percent threshold. The electoral law limited the amount of campaign spending per candidate (Law C of 1997) but the parties chose to overlook this legal requirement. Parties tended to overspend; some even went bankrupt (Ilonszki 2008). Party finances, particularly in the campaign period, were scattered with corruption scandals and dubious relations between private enterprises and parties - leading to loyal entrepreneurs being awarded government contracts (Enyedi 2007).

In addition to the above-mentioned proportionality and financial concerns, some other issues were also at stake - and gained importance during the formation of the new electoral design. After 1990, no redistricting had taken place, despite natural population movements. This situation had been already criticized by an official statement of the Hungarian Constitutional Court in 2005 
and also ran counter to the advice of the Venice Commission which suggested that a 10 percentage point difference was acceptable, and a 15 percentage point difference the highest level tolerable between the populations of the SMDs. More than half of the 176 SMDs in Hungary exceeded this 10 percent difference threshold and close to one third exceeded the "intolerable" 15 percent difference. The most extreme example involved the population size of the most and the least populated SMD being different by a multiple of 2.75 (László 2012). One can justifiably claim that, by any standards, redistricting was due.

Candidate nomination procedures were criticized, virtually from the first moment of the new democratic system. A candidate was required to collect 750 so-called nomination slips in the SMDs to qualify to run. Although this number may not seem to be high, it was increasingly difficult to fulfil the task, particularly for smaller parties, for two reasons. First, large parties with ample resources were quick to collect the slips - raiding their district and collecting many more than they needed to 'qualify' - thus the small parties could not reach out to the most accessible voters. Second, this method made election fraud possible: exchanging nomination slips for money (or goods) was not uncommon. Moreover, as nomination slips were posted to voters together with their registration slips which contained personal data about the voters, it became common practice to steal nomination slips from citizens' post-boxes. With the help of this personal data the slips could be filled in and used to support a party 'in need'. It was also fortuitous to some that voters, by handing over their nomination slips to a party (candidate), disclosed their party preferences. These nomination slips were taken to the local election committee for verification, and although they should have been destroyed afterwards, their confidentiality remained an issue.

Finally, it should be mentioned that the Hungarian electoral system was widely claimed to be too complicated and hard to understand (Benoit 1996, Schiemann 2001). At the time of its formation one legislator complained that it was so complicated that "the voters, if they want to understand it, will have to take at least one course on vote calculation" (cited by Schiemann 2001:231). There is no hard evidence about this issue, but the combination of three tiers and two votes and the compensation mechanism were probably difficult to understand at first glance. Still, as demonstrated by the academic literature, Hungarian voters were informed as they tended to vote strategically (Duch and Palmer 2002, Benoit 2001) and by way of ticket splitting between their SMD and territorial list voting, ensured the survival of small parties ${ }^{2}$.

2 From a broader perspective it is worth noting that even complex electoral systems like mixed member ones show the expected effects and have stimulated the strategic behavior of voters early on in new democracies (see Moser and Scheiner, 2009; Riera, 2013). 


\section{THE MOMENT OF CHANGE - WHY, WHEN, AND WHAT?}

In post-communist new democracies, electoral system changes occurred largely in the initial period of democratization and then became less frequent and less substantial. In the second decade after initial modifications were made, significant changes to electoral systems became even less frequent as attempts to this end failed (Nikolenyi 2011). This condition makes the Hungarian transformation interesting in itself. Moreover, wherever an electoral system change was introduced, unlike in Hungary, it happened in the direction of

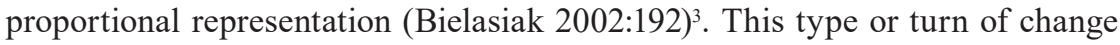
warns that the electoral system should be approached as both an independent and a dependent variable (Leyenaar - Hazan 2011:438) as contextual causation is as important as the actual outcome of the electoral design.

The WHY question is not that difficult to answer, even if at first glance it may seem obvious that it is not in the interest of a governing party who are the majority and are in charge of any transformation to change an electoral system that brought them victory. But parties may fear coming elections and want to consolidate their positions with new regulation (Katz 2015). This approach strengthens the perspective that the motivation of a party is paramount in electoral system change. As Nunez and Jacobs add (2016), electoral system changes can be understood as located in a complex matrix of constraints and opportunities: changes of government, crisis momentum, and electoral volatility may all work in favor of new regulation. The Hungarian case supports these arguments.

Clearly, changing the rules of the electoral game has been on the agenda in Hungary for some time. In the 1994-98 parliament and government term all-party negotiations resulted in an agreement to decrease the size of the parliament and increase its representative context. Still, disagreements about some other concrete issues meant that the parliament's final decision fell five votes short of the constitutional majority required for change. During the term of the next government (1998-2002) a parliamentary commission was even set up, but results were inconclusive. The desire to decrease the size of parliament was a common denominator among the parties, but deep divisions prevailed regarding the share of the nominal and list tiers, and regarding one-round or two-round ballots in SMDs, which have a direct impact on the chances of both smaller and bigger parties and also determine the rules of party cooperationcompetition. Fidesz (the senior governing party at that time) proved to be the

\footnotetext{
3 One possible exception in this regard was the electoral system change in Romania in 2008, which however was soon 'retransformed'.
} 
most persistent at arguing to maintain the majority run off system in SMDs and to favor governability as opposed to representation. Although electoral system change remained a reoccurring theme in the subsequent terms, diverging party interests and the polarized political landscape undermined not only the reform consensus but the interest in reform as well.

The TIMING of the reform is connected to the why question and also illuminates the background process - why was the post-2010 period appropriate for the change? We argue that the failure and the collapse of the party cartel was the main reason (Ilonszki - Várnagy, 2014). The political-constitutional framework hammered out during the democratic transition in 1990 ensured the participating parties a safe position: the regulations of the electoral system protected them from external challengers and the cartel fulfilled claims for stability and governability. While all partisan actors who participated in the agreement were satisfied, there was no motivation for change. Later, when dissatisfaction grew, none of them were in the position to pursue fundamental transformation singlehandedly, as this would have required a two-thirds majority agreement. Thus the old system remained. When the integrity and the popularity of the left was challenged and the earthquake election in 2010 destroyed the remains of the bipolar framework (Enyedi - Benoit 2011) time was ripe for the evolving and dominant party Fidesz to introduce major reforms, including electoral system change. Moreover, two fundamentally political phenomena influenced the direction of the change: first, an understanding that the former partisan bipolarity had been replaced by a tri-polar framework in which a divided opposition had emerged: a fragmented left (including the oncelarge party MSzP and a small green party, LMP) and an extreme right (Jobbik) - and that any cooperation between the left and the extreme right would be excluded by all means. Second, that among these conditions the Fidesz-KDNP party alliance could enjoy a lasting position of relative majority but also that such 'overrepresentation' (that is, a two-thirds majority) would normally require particular political conditions and thus was associated with an air of uncertainty. On these grounds the new electoral design was created to fulfil two requirements: to provide extra advantages to the largest party so that it could benefit from a two-thirds majority, while a party with only a modest relative majority could not become predominant.

It seems that by 2011 there was ample partisan motivation to drive electoral system change, while some normative claims also appeared to be justified. However, the information provided to voters did not reflect these normative claims. Electoral reform was poorly and one-sidedly framed in public discourse, and the entire process involved a serious lack of transparency and public and political scrutiny (Tóka 2013). The new electoral law (CCIII of 2011) was 
accepted despite protest from the opposition parties, with Jobbik voting against and MSZP and LMP abstaining from the vote.

Public debate was focused on three elements of the reform: parliament size, minority representation, and voter registration. Due to political calculations and the very limited timeframe, the rest of the proposed and accepted changes were only discussed after the legislation had passed. The main explanation given for the reform was that parliament needed downsizing, which was an easy point to sell, with populist overtones: too many politicians cost too much money. This was one of the (very few) campaign slogans and promises of Fidesz in 2010. Interestingly, even candidates who agreed with the prospective reduction in the number of mandates were carefully selected at that time. Neither the reduction of seats from 386 to 199 nor the elimination of mandate accumulation (joint occupation of parliamentary and local mandates) triggered any obvious intra-party debate, although both had substantial effects on the political career opportunities of many Fidesz politicians. Unsurprisingly, after the 2014 elections the party faithful former parliamentarians or MPs-cum-mayors were compensated with some of the spoils (Dobos - Kurtán - Várnagy, 2016).

In addition to parliament size, minority representation appeared among Fidesz' party promises, including minorities living in Hungary as well as ethnic Hungarians living outside state borders. In the latter case, the symbolic connection between Hungary and the ethnic Hungarian minority groups was strongly emphasized. In contrast, the opposition focused on the idea of voter registration, initially also part of the new regulation. The register of voter domicile had been well established (mainly based on the system inherited from the communist era, with its deep surveillance system) thus voters did not have to register directly in order to vote. Still, the rule-makers wanted to introduce a new regulation through which voter registration was required. Registration was finally ruled out by the Constitutional Court which came to the conclusion that pre-registration would restrict the right to vote, without constitutional justification (1/2013. (I. 7) thus the governing Fidesz-KDNP party alliance had to revoke this proposition.

Given the many concerns and the few promises, WHAT did the electoral reform actually entail? Table 1 offers an overview of the electoral system before and after the 2011 reform. As the size of the parliament almost halved, the number of SMDs also decreased, but their share in the distribution of mandates increased. Under the previous electoral system 45.6 percent of mandates were distributed in SMDs which yielded highly disproportional results, especially in the 1990s. With the reform, the proportion of mandates distributed in SMDs increased to 53.3 percent, thus reinforcing the majoritarian tendency of the electoral system. SMDs have always been won by large parties. This reached an 
extreme during the 2010 earthquake elections when Fidesz gained 174 out the 176 SMD mandates.

Table 1. The Hungarian Electoral System before and after 2011

\begin{tabular}{|c|c|c|}
\hline & Electoral system pre-2011 & New electoral system \\
\hline Size of parliament & 386 & 199 \\
\hline Number of tiers & 3 & 2 \\
\hline No. of SMDs & 176 & relative majority \\
\hline Ballot in SMDs & majority run off & none, eliminated \\
\hline Number of regional lists & 20 & none \\
\hline $\begin{array}{c}\text { Formula used on regional } \\
\text { list }\end{array}$ & Hagenbach-Bischoff & 1 \\
\hline National list & no vote, served as a & d'Hondt \\
\hline $\begin{array}{c}\text { Ballot on national list } \\
\text { compensatory list }\end{array}$ & d'Hondt & $\begin{array}{c}\text { non-preferential vote } \\
\text { preferential quota for winning } \\
\text { mandate, }\end{array}$ \\
\hline $\begin{array}{c}\text { Formula used on national } \\
\text { Representation of ethnic } \\
\text { minorities }\end{array}$ & none & $\begin{array}{c}\text { ethnic spokesperson in case of } \\
\text { not winning a mandate }\end{array}$ \\
\hline
\end{tabular}

Source: Authors' compilation

Obviously, the rule maker's intention was to maintain this advantage. Two particular measures - namely, the replacement of majority run off with a one-round (first-past-the-post, FPTP) election in SMDs and the facilitation of candidate nomination - served this purpose well. According to the new rule, obtaining a relative majority of the vote was enough to gain a SMD mandate, while formerly 50 percent of votes were required in the first round. The voter participation threshold was also eliminated, further contributing to the low winning threshold. Even more importantly, the elimination of the second round totally transformed the dynamics of the political game. Formerly, the parties used the time between the two rounds to forge potentially winning alliances for the second round, but the new rules encourage parties to form strategic alliances prior to elections. This offers a more transparent choice to voters but pre-election alliances can be risky if partners are not fully informed about the district's political and personal leanings; moreover, this set-up weakens smaller parties which become less visible without a candidate, not to mention the vague chances of cooperation occurring within a highly polarized opposition.

The transformed system for nomination is possibly the best illustration of how a necessary corrective measure can become distorted, and how partisan 
vote-maximizing considerations win in the end (see particularly László 2015). According to the new regulations, voters are entitled to support as many candidates (parties) as they want by signing so-called recommendation forms and providing their personal identity number. This method indeed creates a greater opportunity for new parties (candidates) to appear on the political scene than the former procedure which allowed the voter only one single nomination. The new and generous financing mechanism (discussed below) is a further source of motivation for new parties (and candidates) to enter electoral politics. If a party is able to run 27 SMD candidates (from the 106 SMDs) in the required regional spread, it may also establish a national list, a financially highly rewarding undertaking. Clearly, the new regulation offers contrasting incentives: parties need to unite in order to be able to win mandates in the one round FPTP election, while the low thresholds for nomination encourage parties to run independently.

Changes concerning the proportional tiers of the electoral system and the linkage between the majoritarian and proportional tiers raise concerns about the equality of votes (Mécs 2014, Reiner 2014). As the territorial lists were eliminated, the national list remained the only proportional tier, but lost most of its compensatory character. Formerly, the national list was used to collect the surplus votes and thus the smaller parties were able to win the majority of their mandates on this tier. Under the new regulation, the national list collects direct votes from voters (as mentioned above, in the old system votes were not cast on the national list at all) while it continues to absorb some votes from SMDs. Nevertheless, while in the old system only the votes cast for the nonwinning candidates in SMDs (and non-winning votes on territorial lists) were transferred to the national tier, according to the new law the surplus votes that are cast for the winning candidates are transferred as well. This means that the overrepresentation of the winner is reinforced by the transfer of the surplus votes which prove to be 'unnecessary' for the winning candidate in the SMDs. ${ }^{4}$ As the strongest party tends to win SMD mandates, the thus-transferred surplus votes enhance the strength of the dominant party in the SMDs. Also, due to the transferred votes the vote component of the different mandates varies, so mandates on the national lists are more 'expensive', thus creating an indirect threshold for smaller parties.

While all the former points indirectly raise concern about the equality of representation, the new electoral system directly addressed representation issues only in relation to ethnic minorities, and neglected to reform practices that affect

\footnotetext{
4 Numerically speaking, these are votes in excess of the number of votes cast for the second best candidate, plus one.
} 
other minorities such as women or youth, despite the obvious representation shortcomings in this regard (Ilonszki 2012). The new electoral system allows minority groups to establish ethnic minority national lists to replace party national lists. Voters can cast a vote on a particular minority national list if they have identified themselves as members of the given ethnic minority group and pre-registered accordingly. This seemingly positive form of discrimination hides real discrimination. By voting for the ethnic minority national list, voters lose their right to participate in the politically relevant party national list vote. Moreover, in the case that a minority list fails to meet the threshold requirement - as in fact happened with all the 13 minority lists - their voters' political representation is seriously affected. Instead, a so-called minority spokesperson is invited to participate in parliament - with limited rights - from the top place on the ethnic minority list.

The question rightly arises: how do the above changes relate to more pragmatic problems such as redistricting and campaign financing concerns, as they occurred in relation to the old system?

The need for redistricting was already evident with the old electoral system and the reduction in the number of parliamentary seats also called for enlarged constituencies. When setting the boundaries, the (previously mentioned) suggestions of the Venice Commission were taken into account. Accordingly, the Hungarian Election Law (Act CCIII of 2011 - section 4(4)) mandates that the population of districts should not vary by more than 15 percent, allowing a more lax requirement of 20 percent variability for prospective revisions in the future. Unsurprisingly, the actual definition of boundaries became highly debated as left-leaning districts tend to have 5,000-6,000 voters more than rightleaning districts (László 2012:9), and in some cases extreme and inexplicable disparities remain or were created (Scheppele 2014). The electoral law also lacks detailed requirements for future redistricting, and thus confirms the findings of earlier academic analysis; namely, that redistricting is based on "authoritarianlike provisions" in Hungary (Popescu - Tóka 2008:262). More concretely, a qualified parliamentary majority is entitled to decide about redistricting, in spite of the ruling of the Constitutional Court that asked for clear outlines about basic requirements, and in spite of the concerns expressed by experts over the lack of application of a specific algorithm (Bíró - Sziklay - Kóczy, 2012).

The rules of campaign financing were modified with the aim of ensuring the greater transparency of party campaign spending. Formerly, the main problem with campaign financing had been the distance between codification and reality. Parties tended to exceed their legally defined budgets for campaigning, and presented stripped-down financial reports to the State Audit Office. In order to bring the legislation more into touch with reality, the new ceiling for campaign 
expenses was increased. Parties are now entitled to financial resources depending on the number of SMD candidates they can field. For example, if a party manages to field candidates in all 106 voting districts, it will be eligible for 600 million HUF. Private financial resources are also available to parties. In the case of SMD candidates, one million HUF is allocated to a treasury card issued by the State Treasury which can be used for campaign financing, only through transfers. If the candidate does not manage to get at least two percent of all votes, they are required to refund the whole sum to the State Treasury. Most importantly, however, parties are not required to provide precise details about their spending. Parties do not have to pay back any state contributions, even if they do not get any votes at all - an exaggerated example, of course, although one which does not sound that extreme when one learns that fake parties have actually run for business reasons.

As a report by Transparency International points out, the problem with the new regulation is not the fact that expected campaign costs are significantly higher than before, but that the spending of this money cannot be controlled. "... around 8 billion HUF went toward the parliamentary elections. The organizations operating the civil campaign monitoring site have earlier already shown that the parliamentary election campaign of the governing parties cost close to 4 billion HUF, Jobbik's a little more than 1.2 billion HUF and that of left-wing parties close to 1.6 billion HUF. According to the law, one party is allowed to spend no more than HUF 995 million on their campaign, of which maximum HUF 703 million can come from state funding" (Transparency International 2013).

Thus, while an increase in the ceiling for campaign spending was necessary in order to better match the reality of the cost of campaigning, the parties still overspent and could not be held responsible due to the very limited power of the State Audit Office (Vértessy 2015). Furthermore, such generous financing also motivated the emergence of so-called fake or 'business parties' that were created for the sole purpose of accessing financial resources, with no intention of participating in political competition. The restrictions are lax, not only regarding expenditure but also contributions. While state funding is the most important source of income for most parties, the amount of private donations is hard to assess as cash may be transferred in support, and there is no limit on donations from individuals. Expert assessments suggest that the financial reports of parties are inconsistent, lack standardization, offer very minimal information and are not easily accessible to the public (Money, Politics and Transparency project database, 2015).

Regarding campaign regulations, the issue of access to media has surfaced in various debates and has provoked criticism and opposition in many instances. Indeed, the first version of campaign regulation simply banned paid political 
advertisements on commercial television channels, while mandating a specified number of (free) minutes on public television for each party. As the main source of political information in Hungary is commercial television (Medián 2014), this kind of strict limitation on the flow of information was struck down by the Constitutional Court as a violation of the right to free speech. Then the government tried to introduce this regulation into the Constitution, but an increase in national and international pressure prompted a revision permitting all parties to advertise in commercial media - but included the stipulation that these advertisements could not be paid for. As a result, not surprisingly, commercial television channels basically chose not to run campaign ads during the 2014 campaign.

The above points demonstrate that the necessary and expected improvements in the old regulatory framework became distorted by political will and/or interest. First and foremost, the new electoral design favors the dominant party in almost all of the above-mentioned dimensions. In terms of disproportionality, the dominant party is overrepresented and will enjoy a stable position while the opposition remains fragmented. Although the existence of clear instances of gerrymandering has been debated in terms of the redistricting process, the winner is certainly not hurt by the new setup. As for campaign finance and other campaign practices, even the rule-makers themselves chose to ignore them, sending an alarming signal about the state of democracy in Hungary. These conditions confirm the claims made in the academic literature that the dominant actor is liable to introduce restrictive rules when its aim is to (re) define the rules of the game. Otherwise, when multiple actors are present in the process of negotiation, institutions that support proportionality are favored to avoid "the risk to become an absolute loser" (Colomer 2005:17).

\section{PROMISES AND RESULTS - THE ELECTORAL SYSTEM IN THE CONTEXT OF ELECTORAL INTEGRITY}

The first trial of the new electoral system took place during the 2014 parliamentary elections when Fidesz-KDNP successfully won 67 percent of mandates, with the Socialist party, Jobbik and LMP winning 19 percent, 11 percent and 3 percent of seats, respectively. During the campaign process it became apparent that the new set of rules made the political campaign process more opaque. First of all, due to the transformed nomination process many new parties were created. As a result, in 2014, 18 national party lists existed, as opposed to 6 in 2010. Generous financing attracted fake parties which operated 
not only financially but also politically in a mischievous way: by confusing voters with similar party names to those that "viable" opposition forces used, or just by appearing in SMDs where the competition was more intense. The share of votes given to the small parties that did not get into parliament was not high. At merely 3.6 percent it was very similar to the figure for 2010, while the voting pattern was significantly different: formerly 'really existing' parties were locked out of parliament and in 2014 only a few of the 14 nonparliamentary parties showed the features of real parties at all: putting it more specifically, they did not campaign to win votes. Also, many scandals arose which resulted in complaints being filed to various authorities in relation to the new nomination process: allegedly, parties collected voters' signatures for candidates in misleading ways, and some were accused even of counterfeiting signatures. While cases of major misconduct were not revealed, these problems did not contribute to the legitimacy of the process, ${ }^{5}$ thus the normative claim of an increase in transparency is unsupported.

As the pre-registration criterion was eliminated through the reform process, the voting process itself was similar to that used in previous elections, but the distribution of mandates differed significantly. Table 2 provides an overview of the number and share of votes and mandates for the parliamentary and nonparliamentary parties, together with the proportionality coefficient. The rulemaker clearly enjoys an advantage: with approximately 45 percent of the vote, it gained more than a two-thirds majority of all seats.

Table 2. Election results in 2014

\begin{tabular}{|c|c|c|c|c|c|c|}
\hline & $\begin{array}{c}\% \text { of votes } \\
\text { cast for } \\
\text { party list }\end{array}$ & $\begin{array}{c}\text { No. of } \\
\text { SMD } \\
\text { mandates }\end{array}$ & $\begin{array}{c}\text { No. of } \\
\text { party list } \\
\text { mandates }\end{array}$ & $\begin{array}{c}\text { Total } \\
\text { No. of } \\
\text { mandates }\end{array}$ & $\begin{array}{c}\% \text { of } \\
\text { mandates }\end{array}$ & $\begin{array}{c}\text { Coefficient of } \\
\text { proportionality }\end{array}$ \\
\hline $\begin{array}{c}\text { Fidesz- } \\
\text { KDNP }\end{array}$ & 44,87 & 96 & 37 & 133 & 68,83 & 1,49 \\
\hline $\begin{array}{c}\text { MSZP- } \\
\text { Együtt- } \\
\text { PM-DK- } \\
\text { MPL }\end{array}$ & 25,5 & 10 & 28 & 38 & 19,10 & 0,75 \\
\hline Jobbik & 20,22 & 0 & 23 & 23 & 11,56 & 0,57 \\
\hline LMP & 5,34 & 0 & 5 & 5 & 2,51 & 0,47 \\
\hline Other & 4 & 0 & 0 & 0 & 0 & \\
\hline Total & 00 & 106 & 93 & 199 & 100 & \\
\hline
\end{tabular}

Source: Választás 2014:16

5 See the OECD/ODIHIR report on the 2014 elections for more detail about complaint management. 
The data in Table 2 clearly demonstrate that the winning party is significantly overrepresented in terms of mandate share in parliament. Clearly, the increased relevance of the majoritarian tier (SMDs) plays a role in this respect, but one new element, the allocation of surplus votes from SMDs to the national list, further strengthened disproportionality in 2014. Table 3 illustrates the size of the lost 'fragment' votes (that originate in lost SMD votes; i.e. ones that did not earn a seat) and winner fragment votes (originating in SMD votes that earned a seat and contributed to reaching the number required to win a mandate). As the numbers show, nearly all surplus votes were used to support the rule-maker.

Table 3. Structure of Votes on the National List for each Party at the 2014 Elections

\begin{tabular}{|c|c|c|c|c|}
\hline & $\begin{array}{c}\text { No. of votes } \\
\text { cast for national } \\
\text { party list }\end{array}$ & $\begin{array}{c}\text { Non-winning } \\
\text { votes cast in } \\
\text { SMDs }\end{array}$ & $\begin{array}{c}\text { Surplus votes } \\
\text { cast in SMDs }\end{array}$ & $\begin{array}{c}\text { Votes cast } \\
\text { through postal } \\
\text { ballot }\end{array}$ \\
\hline Fidesz-KDNP & 2142142 & 176193 & 766708 & 122588 \\
\hline $\begin{array}{c}\text { MSZP-Együtt- } \\
\text { PM-DK-MLP* }\end{array}$ & 1289309 & 1119320 & 22374 & 1495 \\
\hline Jobbik & 1017550 & 1000636 & & 2926 \\
\hline LMP & 268840 & 244191 & & 573 \\
\hline
\end{tabular}

*From the parties that constituted a left-wing block and established a common national list and also ran common candidates in SMDs, only MSzP had a pre-electoral reform history. Introduction of the diverse background of these new parties would exceed the limitations of this article. Source: Választás 2014:19.

The last column in Table 3 contains a further element that does not directly demonstrate the majoritarian turn, although it illustrates the vote-maximizing intentions of the law-maker. For the first time in 2014, non-resident ethnic Hungarians who had applied for citizenship (granted by the new Basic Law) were allowed to vote at parliamentary elections. This brought in an additional 128000 votes, 95 percent of which were cast for the governing Fidesz-KDNP coalition, securing them one additional parliamentary mandate. Although granting the right to vote to ethnic Hungarians did not affect substantially the outcome of the elections, it sent a strong symbolic message. The voting procedure applied to ethnic Hungarians living abroad created controversy as these individuals were permitted to vote through postal ballot - unlike the couple of hundred thousand Hungarians working in other European Union countries.

Both the surplus votes that compensated the winner and the votes from non-resident ethnic Hungarians strengthened the dominant party's position. Without these votes, the Fidesz-KDNP coalition would have won 30 mandates on the national list, instead of the 37 mandates they actually acquired. All 
these characteristics indicate a weakening of the compensatory potential of the electoral system, which increases disproportionality.

The overall result of above-mentioned changes is that proportionality substantially declined in 2014. Looking at the Loosemory-Hanby (L-H) index of proportionality, a further feature may be observed: the new electoral system indeed lessens proportionality in mandate distribution (with the L-H index increasing to 21.77 from 15.4$).{ }^{6}$ We should note, however, that proportionality is not only determined by instrumental tools such as the L-H index - which shifted significantly during the first two decades of democratic elections (ranging from 21.15 in 1994 to 6,5 in 2006): this is the party system, whose features have explanatory value as well. ${ }^{7}$ The finding is consistent across different indices of disproportionality (see Gallagher 2017).

The spectacular impact of the electoral system may be observed in the opposition parties' troubled electoral strategies. As already mentioned above, the one-round electoral design of SMDs forced the fragmented left to run one common candidate to potentially challenge the dominant party, but the twosided, polarized opposition (the left and the extreme right) could not cooperate. In fact, they were the strongest rivals; the difference in votes between the left and the extreme right candidates being less than 10 percent in approximately twothirds of the SMDs (70 from 106). This context clearly demonstrates that parties who implement electoral system changes "may want to change the whole format of the party system including both the identity or the number of the parties and the patterns of competition among them" (Katz 2005: 62). In fact, the left-wing parties chose to run common candidates in SMDs, as well as a joint list, which did not promote their electoral chances (and results) in the face of programmatic differences and personal conflict. These problems clearly benefited the dominant party which was able to win a relative majority in the face of two, almost equally strong, alternatives - and with the help of new regulations, transform the win into a two-thirds majority.

Having examined the mixed and controversial outcome that evolved from a combination of normative and partisan claims, an internationally focused general analysis also helps in this evaluation. For this purpose we have used the electoral integrity frame. Table 4 provides an overview of the evaluation of the

6 The higher the index, the lower the level of disproportionality.

7 Stumpf and Kovács emphasize that the transfer of surplus votes only has a significant effect if there is a dominant party in the electoral race. When the competition is tight between - usually two - candidates, the winner's small margin of victory does not translate into a significant number of votes for transferring (2015:57). However, if there is a dominant party which has a significant margin of surplus votes, such transfers further strengthen its parliamentary position. Indeed, the L-H index would have decreased to 18.75 (instead of 21.77) without the effect of the surplus votes. 
15 elections held in European countries in 2013-14. ${ }^{8}$ The project measures using indices eleven different aspects of an electoral system, which are as follows: electoral law, electoral procedures, voter registration, party and candidate registration, media coverage, campaign finance, voting process, vote count, results, and electoral authorities. As Table 4 shows, Hungary's ranking is strikingly low for almost every element - often last -, and always less than the mean value for other European countries both in Western Europe and Eastern Europe.

Table 4. Overview of most Important Indexes of Electoral Integrity for Selected Western and Eastern European EU Member Countries

\begin{tabular}{|l|c|c|c|c|c|c|c|}
\hline & \multicolumn{3}{|c|}{$\begin{array}{c}\text { West European } \\
\text { countries* }\end{array}$} & \multicolumn{2}{c|}{$\begin{array}{c}\text { East European } \\
\text { countries** }\end{array}$} & Hungary \\
\hline & N & Mean & $\begin{array}{c}\text { Std. } \\
\text { Dev. }\end{array}$ & N & Mean & $\begin{array}{c}\text { Std. } \\
\text { Dev. }\end{array}$ & Mean \\
\hline 1-4. Electoral laws index (20-100) & 7 & 76.6 & 12.4 & 7 & 69.7 & 15.9 & 44.5 \\
\hline $\begin{array}{l}\text { 2-5. Electoral procedures index } \\
\text { (25-100) }\end{array}$ & 7 & 88.0 & 6.1 & 7 & 78.7 & 11.2 & 74.3 \\
\hline $\begin{array}{l}\text { 3-4. Voting district boundaries index } \\
\text { (20-100) }\end{array}$ & 7 & 71.3 & 10.8 & 7 & 67.3 & 17.6 & 45.7 \\
\hline $\begin{array}{l}\text { 4-4. Voter registration index } \\
\text { (20-100) }\end{array}$ & 7 & 82.6 & 6.2 & 7 & 73.9 & 21.2 & 79.4 \\
\hline $\begin{array}{l}\text { 5-6. Party and candidate registration } \\
\text { index (20-100) }\end{array}$ & 7 & 78.3 & 4.7 & 7 & 77.7 & 10.5 & 66.5 \\
\hline 6-6. Media coverage index (20-100) & 7 & 63.8 & 4.5 & 7 & 56.9 & 8.8 & 44.9 \\
\hline $\begin{array}{l}\text { 7-6. Campaign finance index } \\
\text { (20-100) }\end{array}$ & 7 & 62.1 & 9.9 & 7 & 57.5 & 10.5 & 46.9 \\
\hline 8-9. Voting process index (20-100) & 7 & 75.4 & 6.4 & 7 & 71.0 & 10.2 & 70.0 \\
\hline 9-6. Vote count index (20-100) & 7 & 87.8 & 9.1 & 7 & 86.5 & 9.8 & 85.3 \\
\hline 10-5. Results index (25-100) & 7 & 83.0 & 6.1 & 7 & 74.0 & 12.1 & 79.2 \\
\hline $\begin{array}{l}\text { 11-5. Electoral authorities index } \\
\text { (25-100) }\end{array}$ & 7 & 84.6 & 5.6 & 7 & 75.7 & 12.3 & 65.9 \\
\hline
\end{tabular}

* Western European countries include: Austria, Belgium, Cyprus, Germany, Italy, Malta, and the Netherlands.

** Central/Central-Eastern European countries include: Bulgaria, Czech Republic, Hungary, Lithuania, Romania, Slovakia, and Slovenia.

Source: Pippa Norris, Ferran Martinez I. Coma and Richard W. Frank. 2014. The expert survey of Perceptions of Electoral Integrity, Release 2.5, (PEI_2.5) July 2014: www.electoralintegrityproject.com.

8 About the project details, see www.electoralintegrityproject.com 
The most critical points in the assessment (those areas in which Hungary scored less than 50.00 points) are the electoral law itself, the voting district boundaries, media coverage and campaign finance. These are poorly ranked, not only compared to Western European democracies but also to Eastern European countries. The assessment of these dimensions is in line with our analysis and supports our findings. Within the integrity framework, electoral law is judged according to how unfair it is to smaller parties, and whether it favors the governing party. The dominance of the majoritarian mechanism, along with the allocation of surplus votes, is detrimental to smaller parties and favors the dominant party - a fact which is mirrored in the disproportional results of the 2014 election. The assessment of voting district boundaries is also based on their level of impartiality, their tendency to support incumbent parties, and to discriminate against others. Campaign financing results are based on experts' views about the accessibility of funds, transparency of usage and proper use of campaign money. As we have argued above, problems in Hungary were not new in this respect, but the indices show that the new regulatory framework did not solve these shortcomings. Analysis of how the media was used during the campaign exceeds the limits of this paper, but the low score suggests that public access to political information is far from satisfactory. In addition to these dimensions, the party and candidate registration index is at rock bottom. In contrast, the voter registration index occupies nearly the highest position - an element that was meant to be eliminated by the first version of the new electoral law. Procedural elements (electoral procedures, voting process, vote counts) are also ranked highly, warning that the low scores concern the political, not the technical aspects of the electoral system.

\section{CONCLUSION}

The integrity of elections has been reduced at several points of the election cycle in Hungary. This case study can add to the ongoing debate about electoral system change in three respects. First, it draws attention to the fact that the value of the electoral integrity frame can be enriched if an electoral system is simultaneously examined as an independent and a dependent variable. Electoral systems have far-reaching social, political, and even systemic consequences, but for a thorough analysis the reasons and intentions behind the design must also be considered.

Second, this analysis of the change of the electoral system in Hungary confirms that electoral systems are "quintessentially distributive institutions" 
(Benoit 2004:366) and efficiency perspectives - our first claim, regarding the necessary corrections to the old design - are only of secondary importance, and are overwritten by partisan interests.

Finally, the majoritarian turn in Hungary has proved to be a device with which to cement the dominant actor and in itself can be evaluated as a move away from established democratic practices (Blais - Massicote 1997). The primary strategic actor appears to be certain of its long-lasting and dominant position which will ensure a reinforced supermajority with the help of the new electoral system rules. Moreover, several elements of the current institutional framework (in addition to, and far exceeding the electoral system) automatically favor the dominant party's interests. In the face of the divided and fragmented opposition, we may be witnessing the construction of a predominant party system (Sartori 1976) on the ruins of failing former institutions. The concern that the monopolies present in predominant party systems are barely affected by democratic processes extends beyond the frame of electoral systems themselves (DiPalma 1990:163).

\section{REFERENCES}

Benoit, Kenneth(1996) 'Hungary's 'Two-Vote' Electoral System' Representation, 33(4):162-170.

Benoit, Kenneth (2001) 'Evaluating Hungary's Mixed-Member Electoral System' in: Matthew Soberg Shugart and Martin P. Wattenberg eds. MixedMember Electoral Systems. The Best of Both Worlds? Oxford University Press, 477-493.

Benoit, Kenneth (2004) 'Models of Electoral System Change' Electoral Studies, 23 (3):363-389.

Bielasiak, Jack (2002) 'The Institutionalization of Electoral and Party Systems in Post-communist States' Comparative Politics, 34(2):189-210.

Biró Péter - Sziklai Balázs - Kóczy Á. László (2012) 'Választókörzetek igazságosan?’ Közgazdasági Szemle, 2012. November: 1165-1186.

Blais, André - Massicotte, Louis (1997) 'Electoral Formulas: A Macroscopic Perspective' European Journal of Political Research, 32 (1): 107-29.

Bowler, Shaun - Todd Donovan (2013) The limits of electoral reform London:Oxford University Press.

Colomer, J. M. (2005) 'It's parties that choose electoral systems (or, Duverger's laws upside down)' Political Studies, 53 (1): 1-21.

Coma, Ferran I Martinez - Carolien van Ham (2015) 'Can experts judge 
elections? Testing the validity of expert judgments for measuring election integrity' European Journal of Political Research, 54: 305-325, doi: $10.1111 / 1475-6765.12084$

Di Palma, Giuseppe (1990) ‘Establishing Party Dominance: It Ain’t Easy’ in: T. J. Pempel ed. Uncommon Democracies: The One-Party Dominant Regimes. Ithaca, Cornell University Press.

Dobos, Gábor - Kurtán Sándor - Várnagy Réka (2016) "A jelöltválasztási folyamat a választási rendszer reformja előtt és után’ in: Dobos et al: Pártok, jelöltek, képviselök. Budapest: Szabad Kéz Kiadó, 118-135.

Duch, Raymond M. - Harvey D. Palmer (2002) Strategic Voting in PostCommunist Democracy?' British Journal of Political Science, 32 (1):63-91.

Enyedi, Zsolt (2007) 'Party Funding in Hungary' in: Daniel Smilov and Jurij Toplak eds. Political Finance and Corruption in Eastern Europe: The Transition Period, Ashgate.

Enyedi Zsolt - Benoit, Ken (2011) 'Kritikus választás 2010. A magyar pártrendszer átrendezödése a bal-jobb dimenzióban' in: Enyedi Zsolt - Szabó Andrea - Tardos R. szerk. Új képlet. A 2010-es választások Magyarországon. Budapest: DKMKA, 17-42.

Fábián György (1999) 'A magyar választási rendszer kelet-közép-európai összehasonlításban' Politikatudományi Szemle, 3: 116-118.

Gallagher, Michael (2017) 'Election indices dataset' accessed March 20, 2017 at http://www.tcd.ie/Political_Science/staff/michael_gallagher/ElSystems/ index.php.

Hazan, Reuven Y. - Monique Leyenaar (2014) 'Understanding electoral reform' New York:Routledge.

Ilonszki, Gabriella - Réka Várnagy (2014) 'From party cartel to one-party dominance. The case of institutional failure' East European Politics, 30(3): 412-427.

Ilonszki, Gabriella (2012) 'The Impact of Party System Change on Female Representation and the Mixed Electoral System' in: Manon Tremblay ed. Women and Legislative Representation. Electoral Systems, Political Parties and Sex Quotas. $2^{\text {nd }}$ updated and revised edition, Palgrave, Macmillan, 211224.

Ilonszki, Gabriella (2008) 'Hungary: Rules, Norms and Stability Undermined' in: Steven D Roper and Janis Ikstens eds. Public Finance and Post-Communist Party Development. ASHGATE, 129-142.

Katz, Richard S. (2005) 'Why Are There So Many (or So Few) Electoral Reforms?' in: Michael Gallagher and Paul Mitchell eds. The Politics of Electoral Systems. Oxford: Oxford University Press, 57-76. 
Kovács László - Stumpf Péter Bence (2014) 'Az arányosságról a 2014-es parlamenti választás után’ Metszetek, 3:52-62.

László Róbert (2012) 'Új választókerületi térkép' in: Political Capital Policy Research and Consulting Institute, Félúton a választási reform.4-12.

László Róbert (2015) 'Még mindig a sötétszürke zónában - az átalakult jelöltállítási és kampányfinaszírozási rendszer’ in: Cserny Ákos szerk. Választási dilemmák. Budapest: NKE, 65-79.

Leyenaar, Monique - Reuven Y. Hazan (2011) 'Reconceptualising Electoral Reform' West European Politics, 34 (3): 437-455.

Medián (2014) 'A politikai tájékozódás forrásai Magyarországon', accessed June 10, 2015 at http://www.median.hu/object.26f0ab59-d464-45fd-b4a0636896caed5b.ivy.

Mécs János (2014) 'A győzteskompenzáció alkotmányosságáról - a pozitív töredékszavazatok megítélése az egyenlő választójog tükrében’ TDK dolgozat. http://www.arsboni.hu/a-gyozteskompenzacio-alkotmanyossagarol-apozitiv-toredekszavazatok-megitelese-az-egyenlo-valasztojog-tukreben. html, accessed July 22, 2015.

Money, Politics and Transparency project (2015) 'The Hungarian case study' https://data.moneypoliticstransparency.org/countries/HU/ accessed 10 June, 2015.

Moser, Robert G. - Ethan Scheiner (2009) 'Strategic voting in established and new democracies: Ticket splitting in mixed-member electoral systems' Electoral Studies, 28 (1):51-61.

Moser, Robert G. - Ethan Scheiner (2004) 'Mixed electoral systems and electoral system effects: controlled comparison and cross-national analysis' Electoral Studies, 23 (4): 575-599.

Nikolenyi, Csaba (2011) 'When electoral reform fails. The Stability of Proportional Representation in Post-Communist Democracies' West European Politics, 34(3):607-625.

Norris, Pippa - Ferran Martínez I Coma - Richard W. Frank. 2014. The expert survey of Perceptions of Electoral Integrity, Release 2.5, (PEI_2.5) July 2014: www.electoralintegrityproject.com.

Nunez, Lidia and Kristof T. E. Jacobs (2016) 'Catalysts and barriers: Explaining electoral reform in Western Europe' European Journal of Political Research, doi: 10.1111/1475-6765.12138

OECD/ODIHIR (2014) 'Limited Election Observation Mission Final Report Hungary, Parliamentary Elections, 6 April, 2014', http://www.osce.org/odihr/ elections/hungary/121098?download=true accessed June 10, 2015

Popescu, Maria - Gábor Tóka (2008) 'Districting and Redistricting in Eastern and Central Europe: Regulations and Practices' in: Handley L. and B. 
Grofman eds. Redistricting in Comparative perspective. Oxford: Oxford University Press, 251-264.

Reiner Roland (2014) 'Így működött a győzteskompenzáció', accessed 10 June, 2015, at http://republikon.blog.hu/2014/04/08/igy_mukodott_a_ gyozteskompenzacio.

Renwick, Alan (2010) 'Changing the Rules of Democracy: The Politics of Electoral Reform' Cambridge: Cambridge University Press.

Rich, Timothy S. (2015) 'Duverger's Law in mixed legislative systems: The impact of national electoral rules on district competition' European Journal of Political Research, 54:182-196.

Riera, Pedro (2013) 'Electoral coordination in mixed-member systems: Does the level of democratic experience matter?' European Journal of Political Research 52: 119-141.

Sartori, Giovanni (1976) 'Parties and Party Systems' Cambridge, Cambridge University Press.

Scheppele, Kim Lane (2014) 'Hungary: An Election in Question. Part V: The Unequal Campaign' http://krugman.blogs.nytimes.com/2014/02/28/hungaryan-election-in-question-part-5, 2014 February 28. accessed June 10, 2015.

Schiemann, John W. (2001) 'Hedging Against Uncertainity: Regime Change and the Origins of Hungary's Mixed Member System' in: Matthew Soberg Shugart and Martin P. Wattenber eds. Mixed-Member Electoral Systems. The Best of Both Worlds? Oxford University Press, 231-254.

Shugart, Matthew (2001) 'Electoral efficiency and the move to mixed-member systems' Electoral Studies, 20(2):173-193.

Singer, Matthew M. (2013) 'Was Duverger Correct? Single-Member District Election Outcomes in Fifty-three Countries' British Journal of Political Science, 43(1):201-220.

Tóka Gábor (2014) 'Constitutional Principles and Electoral Democracy in Hungary' in: Ellen Bos - Kálmán Pócza eds. Constitution Building in Consolidated Democracies: A New Beginning or Decay of a Political System? Baden-Baden: Nomos Verlag, 311-328.

Transparency International (2013) 'Bill on campaign financing - much ado about nothing' http://transparency.hu/Bill_on_campaign_financing Much_ ado_about_nothing?bind_info=tag\&bind_id=41, accessed June 10, 2015.

Választás'14 (2014) A Republikon Intézet választási elemzése. Budapest: R.I. Vértessy László (2015) 'A választások és a választási kampány finanszírozása' in: Cserny Ákos szerk. Választási dilemmák. Budapest: NKE, 81-113. 